\title{
Pembuatan Pakan Berbasis Bahan Lokal dan Saluran Distribusi Melalui E-Commerce Pada Usaha Peternakan Ayam Petelur Desa Teppo Kabupaten Sidenreng Rappang
}

\author{
Aksal Mursalat ${ }^{1 *}$, Muh. Irwan $^{2}$ \\ 1, 2, Universitas Muhammadiyah Sidenreng Rappang \\ ${ }^{1}$ aksalmursalat@gmail.com, ${ }^{2}$ muhirwanprima@gmail.com
}

\begin{abstract}
Abstrak
Permasalahan yang dihadapi mitra adalah kurangnya pengetahuan tentang pembuatan pakan sendiri, dan distribusi pemasaran masih tergolong sempit karena hanya bergantung pada pedagang pengumpul serta kurangnya penerapan sistem informasi melalui media e-commerce. Solusi yang ditawarkan bagi Peternak Ayam Ras Petelur Di Desa Teppo kecamatan Tellu Limpoe Kabupaten Sidenreng Rappang adalah membekali mitra dengan memberikan pelatihan pembuatan pakan berbasis bahan pakan lokal serta memperluas saluran distribusi dengan memanfaatkan sistem e-commerce "Agribisnis Store". Metode pelaksanaan yang dilakukan bersifat parsipatori dimana dalam pengabdian ini tim dan mitra secara proaktif terlibat langsung dalam melaksanakan kegiatan dengan memberikan pelatihan dan praktek langsung dalam pembuatan pakan ayam ras petelur berbasis bahan pakan lokal, penyuluhan model pemasaran dan pendampingan dalam penggunaan aplikasi "Agribisnis Store". Hasil yang telah dicapai pada kegiatan pengabdian ini, yaitu adanya peningkatan pengetahuan dan pemahaman mitra dalam pembuatan pakan berbasis bahan pakan lokal sehingga mitra peternak ayam ras petelur dapat membuat pakan sendiri dengan bahan-bahan yang bisa diperoleh di daerah setempat dan mampu mengurangi biaya pakan yang masih tergolong sulit dan harganya mahal, selain itu mitra juga dapat memperluas saluran distribusi dengan menerapkan sistem e-commerce "Agribisnis Store".
\end{abstract}

Kata Kunci: ayam petelur, pakan lokal, e-commerce, Agribisnis Store

\section{Pendahuluan}

Kabupaten Sidenreng Rappang merupakan penyedia pangan lokal di Sulawesi Selatan salah satu dari pangan lokal tersebut adalah telur ayam ras. Usaha ini mengalami perkembangan yang cukup pesat dan dapat dilihat dari peningkatan jumlah populasi ternak ayam ras petelur. Menurut data Badan Pusat Statistik, jumlah populasi ayam ras petelur di Kabupaten Sidenreng Rappang pada tahun 2019 mencapai 5.238.373 ekor. Mitra pada kegiatan pengabdian ini adalah peternak ayam ras petelur di Desa Teppo Kecamatan Tellu Limpoe Kabupaten Sidenreng Rappang yang merupakan daerah usaha peternakan ayam ras petelur. 
Berdasarkan hasil observasi dan wawancara tim pengusul dengan peternak ayam ras petelur maka, diperoleh informasi bahwa usaha peternakan ayam ras petelur mitra merupakan warga asli penduduk Desa Teppo Kecamatan Tellu Limpoe Kabupaten Sidenreng Rappang yang telah beroperasi lebih dari 10 tahun, dengan total populasi 3.000 ekor ayam dan produksi telur mencapai 2.500 butir telur persekali panen. Usaha peternakan ayam ras petelur mitra di Desa Teppo Kecamatan Tellu Limpoe Kabupaten Sidenreng Rappang pada umumnya melakukan sistem usaha secara mandiri. Ada beberapa permasalahan yang mereka hadapi selama ini dalam usaha peternakan ayam petelur.

Permasalahan yang sering mereka hadapi adalah pakan yang digunakan untuk menunjang proses produksi masih tergolong sulit dan harganya mahal karena diperoleh dari pembelian pakan pabrikan di perusahaan. Pembelian pakan yang dilakukan oleh kedua mitra membutuhkan biaya rata-rata perhari yakni Rp 1.800.000/3000 ekor, jadi dalam perbulan peternak harus mengeluarkan biaya kurang lebih Rp 54.000.000/3000 ekor. Tentunya hal tersebut tidaklah mudah bagi peternak untuk mengeluarkan biaya sebanyak itu dalam sebulan. Penggunaan sumberdaya lokal sebagai bahan baku pakan ternak ayam ras petelur cukup prospektif dikembangkan didaerah untuk mengurangi biaya. Hal ini sejalan dengan (Akhadiarto, 2015) yang mengemukakan bahwa dengan pembuatan pakan sendiri, hasil yang ingin dicapai adalah pakan dengan harga murah, namun tetap memenuhi syarat nutrisi ayam. (Sigit et al., 2017) juga mengemukakan pemberian pakan alami merupakan salah satu bahan lokal yang sangat baik digunakan untuk ayam petelur karena harganya murah, mudah didapat, nilai gizinya cukup baik serta tidak bersaing dengan kebutuhan peternak.

Selain itu di tengah pandemi Covid-19 segala aspek kehidupan cenderung mengarah pada situasi "New Normal" yang memaksa masyarakat mengurangi aktivitas di luar rumah dan aktivitas sosial lainnya termasuk didalamnya perubahan situasi pada aspek saluran distribusi pangan. Mengacu pada hal tersebut maka distribusi hasil produksi menjadi salah satu permasalahan yang dihadapi oleh mitra sehingga menyebabkan terjadinya penumpukan hasil produksi. Berdasarkan hasil wawancara dengan mitra biasanya sebelum pandemi Covid-19 terjadi mitra bisa menjual hingga 500 rak/minggu, namun selama pandemi Covid-19 mitra hanya mampu menjual 200 sampai 300 rak/minggu. Hal ini disebabkan karena terbatasnya akses untuk mendistribusikan hasil produksi secara masif oleh pedagang pengumpul akibat pandemi Covid-19. Kondisi ini menyebabkan mitra mengalami kerugian karena telur ayam ras yang dihasilkan tidak dapat terjual, sementara biaya produksi terus meningkat. Oleh sebab itu, inovasi proses distribusi produk perlu dilakukan dan diimplementasikan kepada mitra agar dapat mendistribusikan hasil produknya secara luas yaitu melalui sistem e-commerce. Menurut (Rahmawati, 2020) layananan e-commerce berperan dalam memudahkan pembelian kebutuhan pangan, serta adaptif terhadap protokol kesehatan saat pandemi Covid-19 (dalam hal ini physical distancing). (Wirapraja \& Aribowo, 2018) juga mengemukakan ecommerce dapat memangkas jalur distribusi menjadi lebih pendek.

Berdasarkan permasalahan yang dihadapi peternak ayam ras petelur di Desa Teppo Kecamatan Tellu Limpoe Kabupaten Sidenreng Rappang, maka lingkup prioritas yang untuk menyelesaikan permasalahan tersebut, yaitu membekali mitra dengan memberikan pelatihan pembuatan pakan berbasis bahan pakan lokal yang bertujuan 
untuk meningkatkan keterampilan mitra peternak ayam ras petelur membuat pakan sendiri dengan bahan-bahan yang bisa diperoleh di daerah setempat. Dengan pembuatan pakan sendiri maka, akan menghemat biaya produksi sekaligus memberikan jaminan ketersedian pakan pada saat harga pakan tinggi. Selain itu, dengan memperluas saluran distribusi dengan menerapkan sistem e-commerce "Agribisnis Store", mitra akan diberikan pelatihan mengenai strategi pemasaran dan pemasaran melalui media online. Perluasan area pemasaran dengan media online ini sangat dimungkinkan karena telur merupakan bahan sembako yang menjadi lauk favorit karena harga yang terjangkau dan sangat kaya akan vitamin. Aplikasi "Agribisnis Store" merupakan sebuah aplikasi pemasaran produk untuk memudahkan konsumen dalam memenuhi kebutuhan seharihari di bidang pertanian, peternakan dan perikanan, aplikasi ini didirikan oleh Program Studi Agribisnis, Fakultas Sains dan Teknologi, Universitas Muhammadiyah Sidenreng Rappang dalam rangka mewujudkan visi misi yaitu "The Digital Entrepreneurship".

\section{Metode Pelaksanaan}

Metode pendekatan yang dilakukan adalah metode yang bersifat parsipatori dimana tim dan mitra secara proaktif terlibat langsung dalam melaksanakan kegiatan, dengan menawarkan pelatihan dan praktek langsung, pendampingan perluasan area pemasaran dengan sistem e-commerce serta evaluasi untuk melihat efektivitas program dalam sosialisasi dan apakah pelaksanaannya efisien. Tahapan-tahapan pelaksanaan kegiatan pengabdian sebagai berikut:

1. Pelatihan dan Praktek Langsung yaitu melalui kegiatan demontrasi pembuatan pakan ayam petelur berbasis bahan pakan lokal. Pelatihan dan praktek ini dilakukan bersama-sama tim dan mitra. Tim sekaligus sebagai narasumber dan instruktur dalam kegiatan ini. Dengan pelatihan dan praktek secara bersama-sama bertujuan untuk menumbuhkan rasa kebersamaan dan kekeluargaan sehingga transfer iptek mampu diserap oleh mitra.

2. Penyuluhan dengan memaparkan model pemasaran teknologi informasi sistem ecommerce aplikasi "Agribisnis Store". Pada kegiatan tersebut tim pelaksana mengadakan penyampaian materi mengenai model pemasaran sistem informasi aplikasi "Agribisnis Store" guna memberikan wawasan kepada masyarakat peternak dalam memperluas saluran distribusi dengan menerapkan sistem e-commerce.

3. Pendampingan penggunaan teknologi informasi sistem e-commerce melalui aplikasi "Agribisnis Store" dengan memberikan pemahaman kepada mitra untuk memanfaatkan sistem e-commerce dalam proses distribusi.
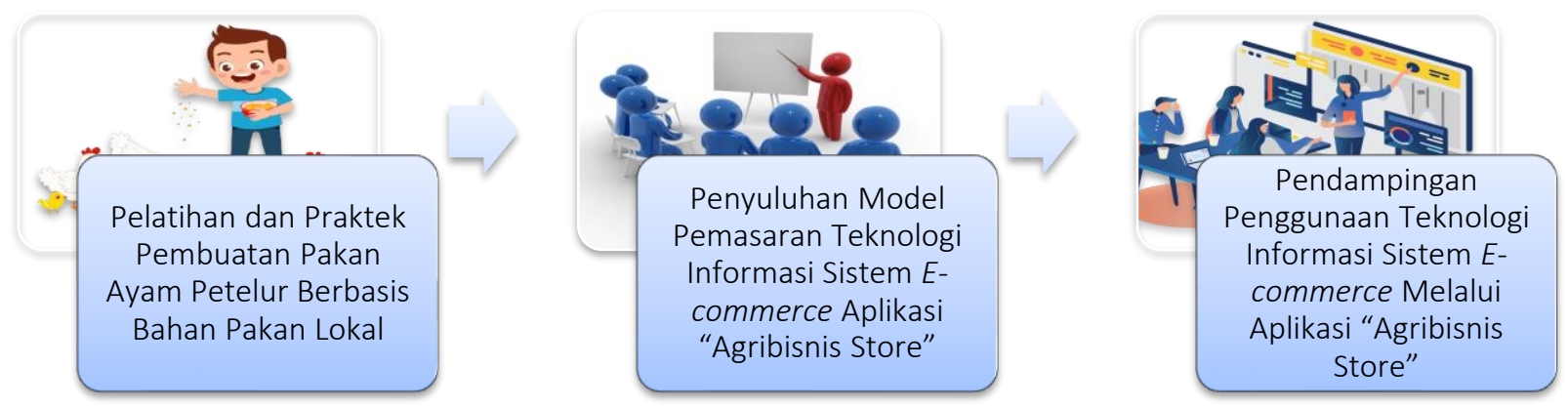

Gambar 1. Metode pelaksanaan yang akan dilakukan bagi mitra usaha peternakan ayam petelur 


\section{Hasil dan Pembahasan}

Dengan adanya pelatihan dan praktek dalam membekali mitra untuk pembuatan pakan berbasis bahan pakan lokal serta memperluas saluran distribusi dengan menerapkan sistem e-commerce "Agribisnis Store", dapat memberikan pengetahuan dan menambah ilmu bagi peternak ayam ras petelur di Desa Teppo Kecamatan Tellu Limpoe Kabupaten Sidenreng Rappang untuk mendapatkan pakan dengan harga murah, namun tetap memenuhi syarat nutrisi ayam serta dapat memangkas jalur distribusi menjadi lebih pendek.

\section{Pelatihan dan Praktek Pembuatan Pakan Ayam Petelur Berbasis Bahan Pakan Lokal}

Pada kegiatan pengabdian kepada masyarakat ini tim memberikan pelatihan sekaligus praktek tentang cara pembuatan pakan ayam petelur berbasis bahan lokal. Bahan pakan yang dikenalkan dalam kegiatan ini berupa dedak jaging, dedak padi, ikan rucah dan bungkil kelapa. Semua bahan yang digunakan diproses ke dalam bentuk tepung dan kadar nutrisinya dihitung berdasarkan kebutuhan ayam petelur. Tujuan dari kegiatan pengabdian ini untuk meningkatkan keterampilan mitra peternak ayam ras petelur membuat pakan sendiri dengan bahan-bahan yang bisa diperoleh di daerah setempat.

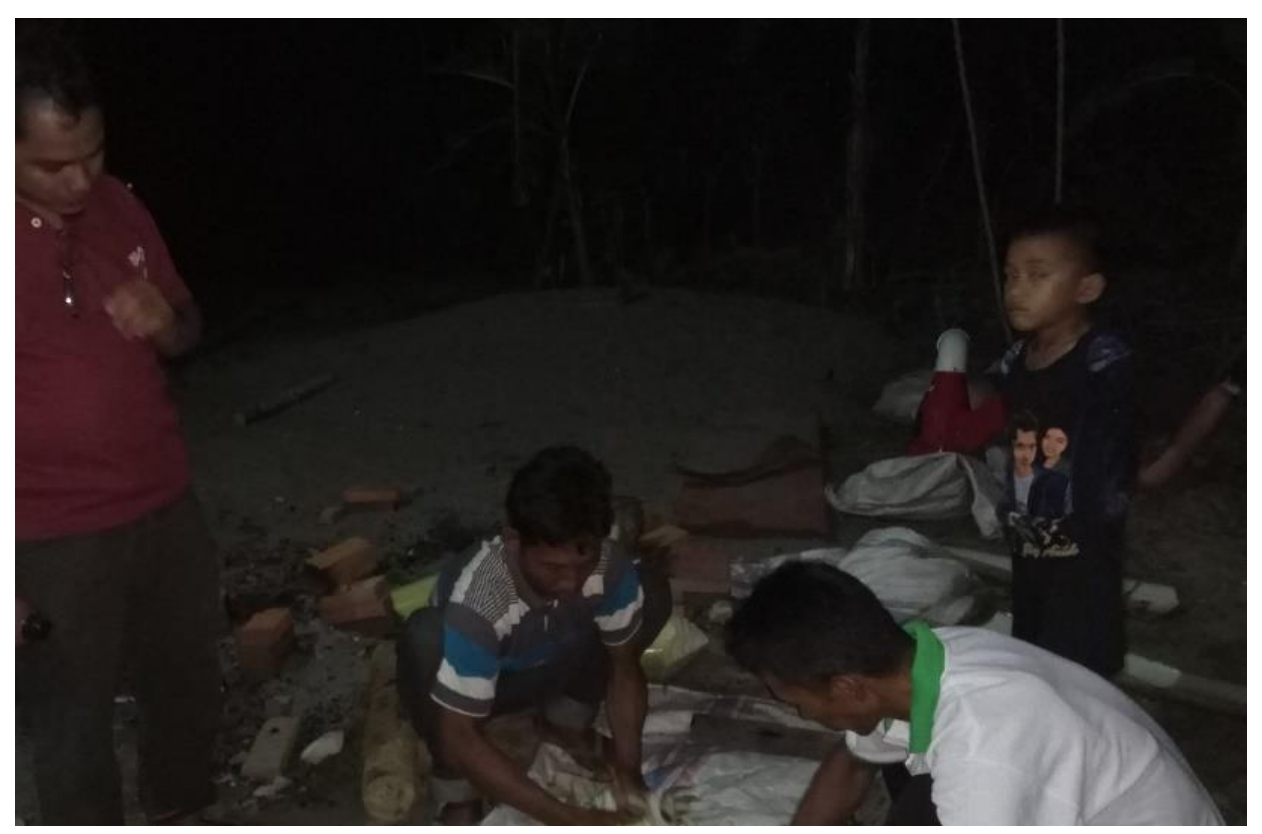

Gambar 2. Pembuatan Pakan Ayam Petelur Berbasis Bahan Pakan Lokal

\section{Penyuluhan Model Pemasaran Aplikasi Agribisnis Store}

Pada kegiatan pengabdian kepada masyarakat ini mitra diberikan materi secara rinci tentang model pemasaran aplikasi agribisnis store. Penyuluhan model pemasaran aplikasi agribisnis store ini dilaksanakan di salah satu rumah masyarakat Desa Teppo Kecamatan Tellu Limpoe Kabupaten Sidenreng Rappang, Sulawesi Selatan. Tujuan dari penyuluhan tersebut untuk memberikan pengetahuan mitra dalam memperluas saluran distribusi dengan menerapkan sistem e-commerce "Agribisnis Store", mitra akan diberikan pelatihan mengenai strategi pemasaran dan pemasaran melalui media online. 


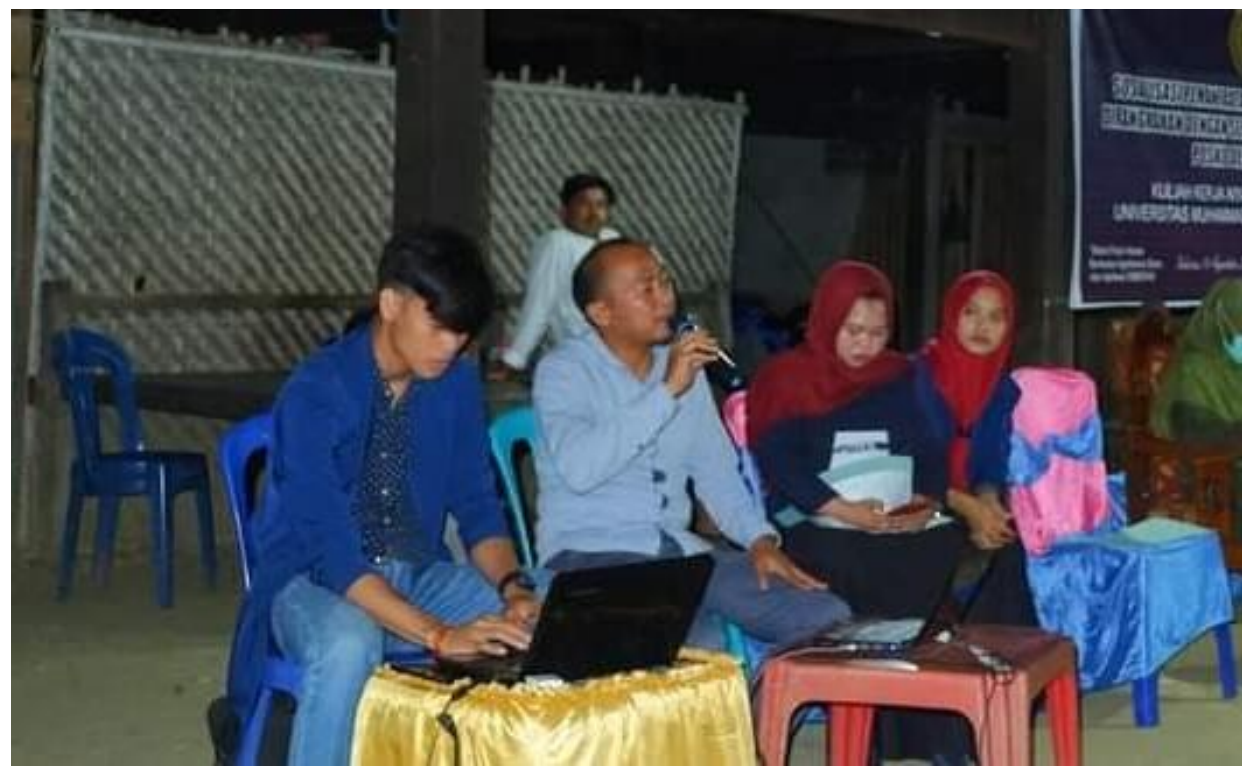

Gambar 3. Penyuluhan Model Pemasaran Aplikasi Agribisnis Store

\section{Pendampingan Penggunaan Aplikasi Agribisnis Store}

Pada kegiatan pengabdian ini, tim memberikan pengetahuan kepada mitra terkait masalah fitur-fitur yang ada dalam aplikasi tersebut dimulai dari aktivitas transaksi jualbeli hasil produk, dan cara mengupload produk ke aplikasi Agribisnis Store. Selain itu, mitra dibimbing untuk menginput data barang produk berupa foto produk, jumlah produk, harga jual serta cara melakukan transaksi melalui aplikasi Agribisnis Store. Selain itu, kami memberikan pengetahuan tentang cara konsumen melakukan transaksi.
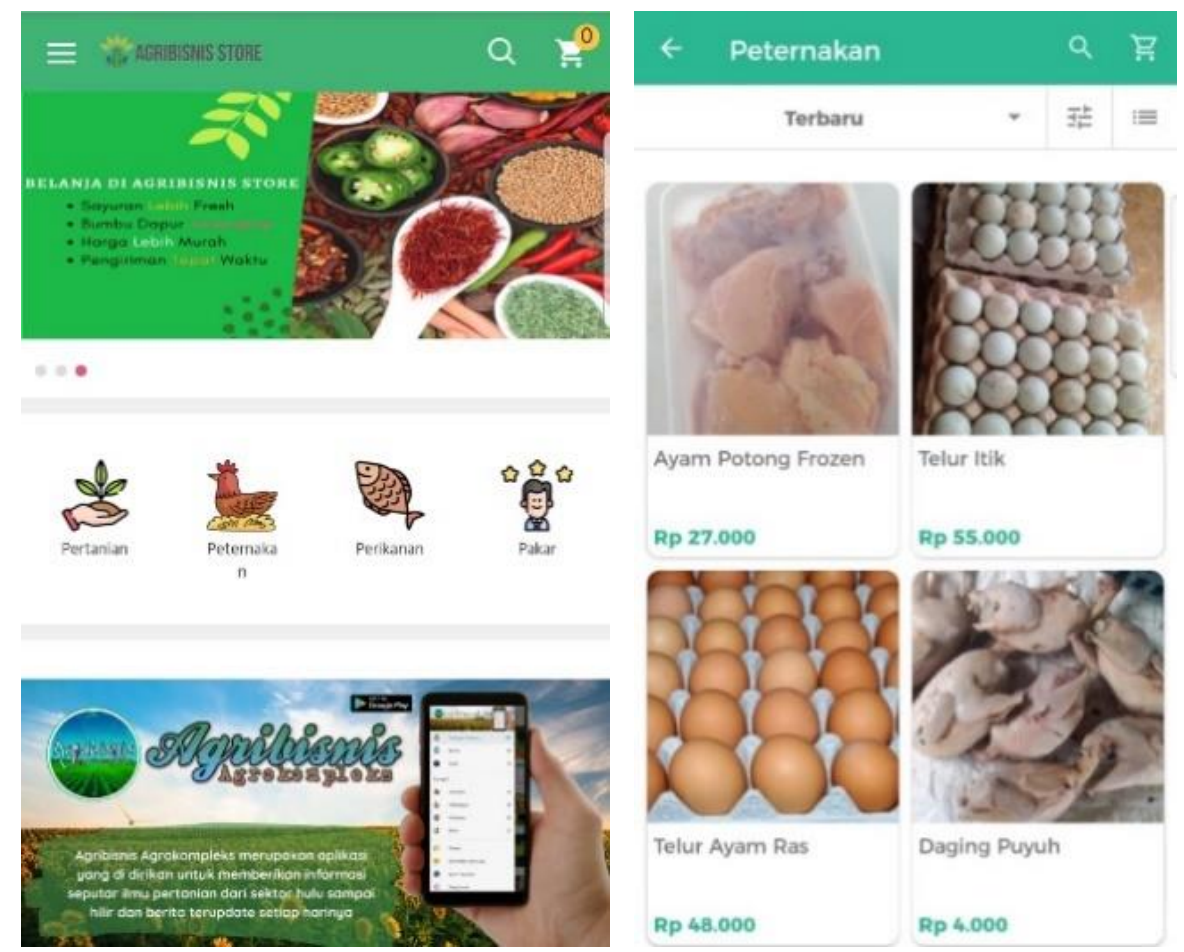

Gambar 4. Tampilan Aplikasi Agribisnis Store 


\section{Kesimpulan}

Hasil yang telah dicapai pada kegiatan pengabdian ini, yaitu adanya peningkatan pengetahuan dan pemahaman mitra dalam pembuatan pakan berbasis bahan pakan lokal sehingga mitra peternak ayam ras petelur dapat membuat pakan sendiri dengan bahan-bahan yang bisa diperoleh di daerah setempat dan mampu mengurangi biaya pakan yang masih tergolong sulit dan harganya mahal, selain itu mitra juga dapat memperluas saluran distribusi dengan menerapkan sistem e-commerce "Agribisnis Store".

Untuk mencapai hasil yang maksimal dalam pembuatan pakan berbasis bahan lokal dan saluran distribusi melalui e-commerce pada usaha peternakan ayam petelur Desa Teppo Kabupaten Sidenreng Rappang, maka akan dilakukan monitoring dan evaluasi terhadap perkembangan mitra dalam pembuatan pakan berbasis bahan lokal dan pemasaran melalui sistem e-commerce "Agribisnis Store" usaha peternakan ayam petelur sebagai bagian dari tanggungjawab dan implementasi tridarma perguruan tinggi, untuk itu disarankan kepada mitra untuk terus membangun komunikasi dan koordinasi yang baik untuk mencapai hasil yang maksimal.

\section{Ucapan Terimakasih}

Ucapan terimakasih disampaikan kepada $\mathrm{LP}_{3} \mathrm{M}$ Universitas Muhammadiyah Sidenreng Rappang serta Kepala Desa Teppo Kabupaten Sidenreng Rappang yang telah mendukung pada kegiatan pengabdian kepada masyarakat ini. Kami juga mengucapkan terimaksih kepada mitra yang telah berpartisipasi dalam melaksanakan kegiatan serta pihak terkait yang telah membantu dalam proses kegiatan pengabdian kepada masyarakat ini. Terimakasih juga secara khusus diberikan kepada pengeditan naskah secara cermat sehingga artikel ini layak diterbitkan.

\section{Referensi}

Akhadiarto, S. (2015). Prospek Pembuatan Pakan Ayam Dari Bahan Baku Lokal (Contoh Kasus Gorontalo). Jurnal Sains Dan Teknologi Indonesia, 17(1), 7-15. https://doi.org/10.29122/jsti.v17i1.3420.

Badan Pusat Statistik (BPS). (2020). Kabupaten Sidrap Dalam Angka 2018. BPS. Kabupaten Sidrap.

Rahmawati, L. (2020). Peran E-commerce dalam Mendukung Ketahanan Pangan Wilayah Jakarta Saat Pandemi Covid-19. Jurnal Kajian Lemhannas RI, 8(2), 11-28.

Sigit, M., Rohmad, \& Abrianto, D. Z. (2017). Pengaruh Pemberian Tepung Buah Dan Daun Mengkudu (Morinda Citrifolia) Terhadap Produktifitas Ayam Petelur Fase Layer. Jurnal Ilmiah Fillia Cendekia, 2(2), 17-26.

Wirapraja, A., \& Aribowo, H. (2018). Pemanfaatan E-commerce Sebagai Solusi Inovasi Dalam Menjaga Sustainability Bisnis. Teknika, 7(1), 66-72. https://doi.org/10.34148/teknika.v7i1.86 